\title{
The Land of Mermedonia in the Old English Andreas
}

\author{
Alexandra Bolintineanu
}

Published online: 8 January 2008

(C) Springer Science+Business Media B.V. 2007

\begin{abstract}
In the Old English poem Andreas, God sends St. Andrew on a mission of mercy to the land of the cannibalistic Mermedonians. Compared to its Greek, Latin, and Old English prose analogues, Andreas elaborates the monstrous customs of the Mermedonians and the geography of their land so as to systematically heighten the otherworldliness of Mermedonia. This emphatic distance between Mermedonia and the rest of humankind develops through the Andreas-poet's use of repetition, of intertextual echoes, and of episodic parallelism within the poem itself. Not only does the otherworldliness of Mermedonia heighten the impact of the country's eventual conversion to Christianity; paradoxically, it also turns Mermedonia into a theological microcosm of the whole world, undergoing its own abbreviated history of salvation.
\end{abstract}

Keywords Andreas · Beowulf · Cannibalism - Christianity · Elðeodig ·

Exile · Geography · Harne stan · Landscape · Mermedonia · Miracles ·

Otherworldly places

\section{The Land of Mermedonia in the Old English Andreas}

Mermedonia is not a pleasant place: its inhabitants, being fond of strangers only in a culinary sense, habitually capture, blind, poison, bewitch, and eventually devour any visitors to Mermedonian shores. Of the several Old English texts that narrate the life

\footnotetext{
A. Bolintineanu $(\bowtie)$

6 Avénue Floréal, Apt. 22, 1006 Lausanne, Switzerland

e-mail: alexandrabolintineanu@gmail.com

Present Address:

A. Bolintineanu

Centre for Medieval Studies, University of Toronto,

125 Queen's Park, Third Floor, Toronto, Ontario M5S 2C7

e-mail: alexandra.bolintineanu@utoronto.ca
} 
of St. Andrew, only three tell of his sojourn in the land or city of Mermedonia. One is the poem Andreas, which appears in the Vercelli Book. ${ }^{1}$ The other two are versions of a homily; a complete version appears in Corpus Christi College Cambridge MS $198^{2}$ and a fragmentary version appears in the Blickling codex (Blickling Homily $X I X){ }^{3}$ All three Old English texts are descendants of the very popular apocryphal narrative of St. Andrew's sojourn among the Mermedonians. Their closest analogues are the Greek Praxeis Andreou kai Matheian eis ten polin ton anthropophagon and the Latin Codex Casanatensis Acta Andrea et Matthice apud anthropophagos. ${ }^{4}$

Although the Greek, Latin, and Old English prose analogues describe and decry the wicked customs of the Mermedonians, Andreas does this at much greater length and with much greater intensity. From the very beginning it emphasizes the Mermedonians' hostility to strangers, their monstrous eating habits, their alliance with the devil, even their geographical remoteness and isolation from the rest of the world. Andreas intensely and systematically represents the land of Mermedonia as a monstrous, otherworldly place, separated by custom and geography from the rest of the world. This carefully developed otherworldliness, this emphatic distance between Mermedonia and the rest of humankind, emerges through the Andreas-poet's use of repetition, of intertextual echoes, and of episodic parallelism. Not only does the otherworldliness of Mermedonia heighten the impact of the country's eventual conversion to Christianity; paradoxically, it also turns Mermedonia into a theological 'type' of the whole world, undergoing its own abbreviated history of salvation.

The most obvious monstrous characteristic of the Mermedonians is their cannibalism; both Andreas and its analogues introduce Mermedonia with reference to this cannibalism, but there are significant differences between its treatment. In Casanatensis, the Mermedonians are very systematic about their monstrous diet. They have developed specialized technology to process their victims' blood and to cook their flesh:

Devenit namque beati mathei in sortem provincie que dicitur mermedonia, in qua conmorabantur iniqui et pessimi viri, nichil aliud preter hominis carnem edebant, eosque sanguinibus bibebant. Habebantque clibanum in medio civitatis edificatum, insuper et lacus iusta eodem clibani. In quo lacu[s] homines interficiebant, ut sanguis illud ibi colligerent. Alioque lacu iusta ipsum lacum, in quo sanguis illud que in ipso priore laco spargentur, ... [textual

\footnotetext{
1 Brooks (1961), cited from here on as And.

2 Cassidy and Ringler (1971), cited from here on as LS 1.1.

3 Morris (1874-80, repr. 1967), cited from here on as Blickling XIX.

4 Of the Greek and Latin recensions of the St. Andrew apocrypha, the closest in content to Andreas and to the Old English homily are the Greek Praxeis Andreou kai Matheian eis ten Polin ton Anthropophagon (abbreviated as Praxeis) and the Latin Acta Andrea et Matthice apud anthropophagos in the Codex Casanatensis (abbreviated as Casanatensis). As Alison Powell notes, scholars agree that neither of these two versions is the direct source of Andreas, but disagree as to which version is closest to the direct source (7-13.) Accordingly, as Powell suggests, I will treat Praxeis, Casanatensis, and the Old English homily "as analogues of Andreas, regarding no particular version as a substitute for a source" (13). For the standard sideby-side edition of the Greek and Latin texts, see the edition of Franz Blatt. For Modern English translations, see Robert Boenig. Henceforth I will refer to the Greek analogue as Praxeis and to the Latin analogue as Casanatensis. I will reference each of these by chapter, page, and line number in the Blatt edition.
} 
lacuna] ... et quasi purgatus discurret, ... [textual lacuna] ... bibendum (Casanatensis cp. 1, p. 3, 11. 4-11). ${ }^{5}$

[And the province which is called Mermedonia fell to the blessed Matthew in the casting of lots, in which lived wicked and very bad men, who did not habitually eat anything other than human flesh, and habitually drank their blood. And they had a baking oven built in the middle of the city, and a large tub above and next to that same oven. In this large tub they used to kill people, so that they would be able to collect that blood there. There was another large tub next to this large tub, in which which that blood which was poured into the first tub ... would run about, purified ... to be drunk. $]^{6}$

They also have a system for tracking their captives' best-before dates:

Et tenentes unusquisque tabula in manu sua, quas iniquissimi et crudeles carnifices, in eorum manibus dederant cum eos retrudebant, erat namque per singula tabula scriptum, numerum dierum triginta, et cotidie introiebant carnifices illi ad eos in eadem carcere, et tabulas illas scripturas contemplabantur. Ut quem per ipsam scripturam invenirent, iam expletis triginta diebus haberet reclusum, velut animalia ad saginandum, statim eiciebant eum qui triginta dies conpleverant, et occidebant, atque judicibus suis preparabant carnes eorum ad manducandum, et sanguis eorum ut potum ad bibendum (Casanatensis cp. 3, p. 37., 11. 11-18).

[And each [of the prisoners] held a tablet in his hand, which the evil and cruel murderers used to give them in their hands when they threw them in jail, and the number of thirty days was written on each tablet, and every day those murderers used to come into that same prison to them, and used to look at the inscribed tablets. Whomever they found by means of this writing to have completed the thirty days of being shut in, just like animals for slaughter, they used to throw out and kill straight away, and their judges used to prepare their flesh for eating and their blood as a potion for drinking.]

Praxeis features a similar food-processing and prisoner-tracking system in its version of Mermedonia (Praxeis cp. 3, p. 36, 11. 15-19). ${ }^{7}$ The Old English homily omits any grisly food-processing details, simply stating that the wicked Mermedonians hlaf ne aton ne water ne druncon, ac aton manna lichaman and heora blod druncon ("neither ate bread nor drank water, but ate men's bodies and drank their blood," LS1.1 11. 4-6).

In Andreas, the narrator also insists on Mermedonian cannibalism; but in the Old English poem, the Mermedonian eating practices are far more savage than in the three prose texts. They are described at first entirely in negative terms. Unlike the more sophisticated Mermedonians of Praxeis and Casanatensis, those in Andreas

\footnotetext{
5 The redactor of the Casanatensis uses Latin grammar idiosyncratically. Note, in the present passage, sanguis for sanguinem. This is a feature of Casanatensis throughout.

6 All translations from the Latin and Old English are my own. For the Greek vita of Andrew (Praxeis), I have consulted Boenig's translation.

7 See Boenig (1991, p. 3 and p. 15) for a description of the tablets and the food-processing facility.
} 
do not appear to process their food in any way; in fact, they even lack the most basic human foods, bread and water:

Næs pær hlafes wist

werum on pam wonge, ne wæteres drync

to bruconne, ah hie blod ond fel,

fira flæschoman, feorrancumenra,

ðegon geond pa peode (And 1l. 21b-24).

[There was no bread for men in that plain, nor a drink of water to enjoy; instead, they [the Mermedonians] consumed blood and skin, the flesh-covering of men, of those come from afar, from beyond that nation.]

Casanatensis also mentions that the Mermedonians have neither bread nor wine; Praxeis implies that they are unwilling to consume them, preferring human flesh instead. Boenig observes that the Mermedonians' diet in the Greek and Latin analogues is a figurative rejection of the Eucharist; in contrast, both the Andreaspoet and the homilist describe the Mermedonians as lacking bread and water rather than lacking bread and wine, a translation that reflects more closely the material culture of Anglo-Saxon England. ${ }^{8}$ This change turns the absence of bread and water into a comment on the literal abnormality of the Mermedonians' diet rather than a symbolic indictment of their spiritual state.

Underscoring this abnormal diet even further, the Andreas-poet makes his Mermedonians' grisly consumption of human beings vivid through an anatomical view of the process, a view that invites the reader to imagine the Mermedonians eating their victims layer by anatomical layer-first the blood, then the skin, and then the underlying flesh. This detailed description of the Mermedonians' eating habits would have been especially monstrous to a Christian Anglo-Saxon audience, whose great religious writers-Bede, Alfred, Ælfric, and Wulfstan-insistently echo "commonplace biblical injunctions against drinking blood." 9 Later in the poem, the Mermedonians' cannibalism reduces them to beasts, as the epithet walwulfas (slaughter wolves) and the vivid description of their table manners suggest:

... swa hit wælwulfas awriten hæfdon

pæt hie banhringas abrecan pohton,

lungre tolysan lic ond sawle ... (And 11. 149-151).

[as the slaughter-wolves had arranged it, when they thought to break the bonerings, quickly separate body and soul.]

The dense alliteration on ' $b$ ' and ' $r$ ' in the second line of the passage and on ' $l$ ' and 's' in the third line onomatopoeically evokes the cracking of bone and slurping of raw meat.

As their appetite makes the Mermedonians sever strangers' souls from their bodies, it makes them sever family ties amongst themselves. When Andrew rescues

\footnotetext{
${ }^{8}$ Boenig (1991, p. xxxiii, p. 1).

${ }^{9}$ Orchard (2003, pp. 140-141).
} 
the foreign captives, the Mermedonians turn on their own people, casting lots for one of them who will become food for the rest. When the lot falls on an old warrior, he offers up his innocent young son to die in his stead, in a reversal of the natural order (Praxeis and Casanatensis cp. 23, pp. 76-77; And 11. 1099-1111; the Old English homilies omit this episode). In Praxeis, the old warrior must involve the Mermedonian executioners' entire chain of command in the decision, and ends up offering both his son and his daughter as a snack for his fellow citizens. In Casanatensis, the scene is even more elaborate: the father offers up his son; the Mermedonians weigh the two; when the son proves lighter, the father offers up his daughter to make up the desired weight. In contrast, the Old English poet simplifies and speeds up the scene: there is only one child, and instead of navigating the chain of command or calculatingly weighing the child, the Mermedonians hungrily rush upon him metes modgeomre ("sad for [lack of] food," And 1. 1113). As before, the Andreas-poet makes his Mermedonians fiercer, more savage, and less calculating than their counterparts in the Greek and Latin analogues; they resemble Grendel more than they resemble the sophisticated anthropophagi of Praxeis or Casanatensis.

Through grammatical parallelism and juxtaposition the poet equates the violent cannibalistic customs of the Mermedonians with their religious allegiance: eal was pat mearcland morðre bewunden,/ feondes facne ("that entire borderland was encompassed by violence, by the fiend's guile", And 11. 19-20). As John Casteen points out, the cannibalism of the Mermedonians is not just a monstrous practice, but a sign specifically of their separation from God; according to medieval exegetes, God punishes a people that forsakes Him by making it cannibalistic. ${ }^{10}$ The Mermedonians' allegiance to the devil becomes apparent in other customs: they indulge in such idolatrous (hœðengildum) and devilish (hellcraftum) practices as casting lots to determine their next victim (And 11. 1099-1105). ${ }^{11}$ The devil eventually appears as their advisor and liege-lord, both in Andreas and in the prose analogues; but the foreshadowing of this allegiance, which occurs only in the poem, delineates the spiritual conflict all the more clearly.

Geography demarcates Mermedonia from the rest of the world as sharply as its customs. The topographical terms that describe it—igland and mearcland-appear to contradict one another; one describes Mermedonia as an island, the other describes it as a border region. What they have in common, however, is the suggestion of otherworldliness. Oliver J. H. Grosz traces the operation of the first term: as he observes, the poem describes Mermedonia as an igland or ealand (And 11. 15, 28), though this detail appears neither in the Greek, nor the Latin, nor the Old English homily. ${ }^{12}$ Considering the historical site of Mermedonia, which is a seacost

\footnotetext{
${ }^{10}$ Casteen (1978, pp. 74-78).

11 In his sermon "On Auguries”, Ælfric condemns magical practices, including pagan casting of lots. Whoever inquires into anything by magic, he states, bið pam haðenum gelic pe hleotað be him sylfum mid ðas deofles crafte pe hi fordeð on ecnysse (is like the heathen who cast lots concerning themselves through the devil's art, which destroys them forever, Skeat 11. 75-6).

12 Grosz (1970, p. 240).
} 
rather than an island, critics have suggested that igland and ealand mean "land bordering on water" or "land beyond the water". ${ }^{13}$ As Grosz points out, however, Andreas is a poem, not a geographical treatise; it might make more sense to look for "artistic motives for the poet's use of igland in its ordinary sense." He then argues that the saints Matthew and Andrew are religious exiles, in the tradition described by Dorothy Whitelock. Accordingly, Mermedonia is an island

not because it is far across the sea, but more precisely because an island symbolizes the religious exile's complete isolation from an outer world. Thus the poet of Andreas has introduced a psychological rather than a factually accurate geography. The island symbolically parallels Matthew's physical incarceration as well as his spiritual isolation from the sinful, heathen world. ${ }^{14}$

But in the literal sense of the story, the saints are not isolated from the "sinful heathen world"; quite the opposite, they are immersed in an exceptionally sinful heathen world, which acts upon them and which they act upon. What they are isolated from is the implied normal world, its customs and its safety. The insularity of Mermedonia symbolically parallels the Mermedonians' initial distance from the human norm and from God.

The second term, mearcland, works more subtly. In his edition of Andreas, Brooks glosses it as "a borderland, waste land lying outside cultivated areas". This fits the Mermedonians' culinary savagery, their lack of a civilization that would produce more ethically acceptable food. Mearcland also connotes otherworldly menace, as the use of borderlands in other Old English poems suggests: in Guthlac $A$, the word mearclond describes the saint's demon-ridden hermitage (1. 174); in Beowulf, borderlands are the stalking ground of Grendel, the more mearcstapa (mighty wanderer of the borders, 11. 103, 1348). ${ }^{15}$ As Manish Sharma points out, "[i]n their imagination, Old English poets seemed to assume a natural relation between evil, especially of the supernatural sort, and border-space."16

The Mermedonians' spiritual distance from the human norm is reinforced by the physical distance between Mermedonia and the rest of the world. The Andreas-poet frequently accentuates this impression of distance. Andrew initially objects to God's command that he travel to Mermedonia, referring to the long journey twice in the same speech: feorne weg ("a long way," 1. 191), wegas ofer widland ("ways over the wide land," 1. 198). Later, God disguised as the ship's captain tells Andrew that he has come a long way from Mermedonia (11. 264-5). Again, during the storm at sea, God warns the missionaries that the journey to Mermedonia will be long and the land distant (11. 420-424). Of all these references to distance, only one appears in one of the prose analogues: in the Old English homily, Andrew offers one brief

\footnotetext{
${ }^{13}$ One such critic, as Grosz points out, is Kenneth R. Brooks, "Old English EA and Related Words" (1952-3). English and Germanic Studies, 5 (1952-53), 28, note 77. Brooks's view coincides with the argument of George Philip Krapp, "Notes on the Andreas" (January 1905), Medieval Philology, 2, 400.

${ }^{14}$ Grosz (1970, p. 242).

${ }^{15}$ Krapp and Dobbie (1936), hereafter cited as Guthlac A and B; Klaeber (1950), hereafter cited as Beowulf.

16 Sharma (2002, p. 200).
} 
objection to the length of the journey to Mermedonia: se sibfaet is pyder to lang, and ic pone weg ne con (the journey there is too long, and I do not know the way, LS1.1 11. 45-6).

A description of the population also reinforces Mermedonia's foreignness. Newly arrived in Mermedonia, Andrew warns his disciples that they are about to undergo martyrdom in the homeland of the almyrcna (And 1. 432). This hapax legomenon has been translated as either "Ethiopians" (literally, all-black people) or as "foreign borderers". J. R. Hall points out the problems with both translations. ${ }^{17}$ Geography speaks against the first meaning: Ethiopia cannot be identified with Mermedonia, since the apostle Matthew was martyred in the former and escaped martyrdom in the latter, and since the latter conspicuously lacks the torrid climate of the former. Linguistic evidence speaks against the second meaning: "there is no recorded instance of *mearce 'borderers' of which myrce might be a variant spelling, [and] *myrc does not occur as a spelling of mearc 'border'." 18 Instead of these two meanings, Hall proposes that aelmyrcna be read as "the wholly dark" in a spiritual sense, a reading supported by the use of myrce as an indicator of evil throughout the poem. However, whether it indicates spiritual standing, geographical position, or skin colour, the saint's reference to the dangers of the land of the almyrcna is in agreement with the general strategy of distancing Mermedonia from the implied "normal world" of the text.

Unlike his Greek, Latin, and Old English prose analogues, the Andreas-poet fleshes out the physical geography of Mermedonia in evocative detail. Andreas's first view of the Mermedonian coast is grim and imposing:

Onwoc pa wiges heard, (wang sceawode),

fore burggeatum. Beorgas steape,

hleoðu hlifodon, ymbe harne stan

tigelfagan trafu, torras stodon,

windige weallas (And 11. 839-43).

[Then the war-hardened man woke up, looked at the place before the city gates. Steep hills, hollow hills towered. Around the grey stone stood tile-adorned buildings, towers, windy walls.]

While Casanatensis only mentions the city gate of Mermedonia, and while neither Praxeis, nor the Old English homilies refer to the setting at all, ${ }^{19}$ the Old English poem describes an interesting juxtaposition of natural and urban features. Many of these topographical features seem to import literary connotations of danger, especially from Beowulf. ${ }^{20}$ For instance, Margaret Gelling argues that hlið or

\footnotetext{
${ }^{17}$ Hall (1987, pp. 38-47).

18 Hall (1987, p. 39).

19 The parallel passages in the analogues are Casanatensis cp. 15, p. 63 ; Praxeis p. 62, cp. 15; LS1.1 11. 96-97. Neither contains a comparable description of Andrew's first view of the city.

${ }^{20}$ I operate on the assumption that the Andreas-poet borrowed directly from Beowulf. For arguments in support of this point, based on the number and the extensive nature of verbal parallels between the two poems, see Alison M. Powell (2002) and Orchard (2003, pp. 163-166).
} 
hleoðu, usually translated as "slope", actually has the specialized sense of "hill with a hollow", a dangerous topographical feature:

A hill with a hollow provides dead ground, and this could be a lurking place for natural or supernatural enemies. In all instances in Beowulf the -hlið, -hleoðu compounds have a menacing context. ${ }^{21}$

Similarly, the noun phrases beorgas steape, windige weallas, and harne stan all occur in Beowulf, and all are in some way associated with danger. The beorgas steape, the steep cliffs, appear in the hero's first view of the Spear-Danes' coast, where he will face the Grendel family. The windige weallas, the windy walls, are Beowulf's first sight of land after the swimming contest with Breca and the battle with sea monsters. The third is the most interesting. Studying its occurrences in Beowulf, Andreas, and other Old English texts (including charters), William Cooke and Michael Swisher agree that the harne stan represents a traditional boundary marker. ${ }^{22}$ However, in Beowulf, in Andreas, and in Blickling XVI, the harne stan marks specifically dangerous, otherworldly places-respectively the Grendel mere, various dragons' lairs, the land of Mermedonia, and hell. Accordingly, Swisher argues that it is a formulaic expression that marks a passage to a dangerous otherworldly space. ${ }^{23}$ Overall, the intertextual echoes "import" an atmosphere of strangeness and danger into Andreas's (and the readers') first impression of Mermedonia's landscape.

A later description of the landscape of Mermedonia, the city streets and the countryside where Andrew suffers martyrdom, is also not parallelled in the prose analogues, and it also echoes Beowulf. ${ }^{24}$ The streets of Mermedonia are stanfage, stone-adorned, like the path towards Heorot, and the buildings are enta argeweorc, the ancient work of giants, like the magical sword in the Grendel lair (And 11. 12291240; Beowulf 11. 320a, 1679a). Here the ancient splendours of the city, like the poet's use of heroic diction to describe the inhabitants, emphasize the violent savagery of the Mermedonians. They live in an artfully built city, but they have neither bread nor drinking water (And 11. 21b-24). They plan a great communal feast, to share their food as Hrothgar and his warriors might in Heorot, but there are people on the menu (And 11. 152-153). They rush into battle, like a valiant warband, but their adversary is a boy whom they want to devour (And 1l. 11161125). They possess a splendid ancient city, but they cannot enjoy the trappings of civilized life, treasure and gabled halls, because they have no people to eat (And 11. 1113-1114, 1158-1162). The familiar heroic language applied in such strange circumstances makes the monstrosity of the Mermedonians all the more evident.

In his discussion of imagined landscapes in Old English poetry, a discussion focused on the exilic landscapes of the Wanderer and of the Wife's Lament, and on

\footnotetext{
21 Gelling (2002, p. 8).

22 Cooke (2003, pp. 297-301); Swisher (2002, pp. 133-136).

23 Swisher (2002, pp. 133-136).

24 Orchard (2003, p. 166).
} 
the monster mere of Beowulf, Nicholas Howe argues that the imagined landscapes are

means of representing the interior, existential crisis that occurs within heroic culture: that of the figure isolated from other human beings, with little if any hope of successfully changing his or her lot in this transitory world. ${ }^{25}$

Andreas is repeatedly a "figure isolated from other human beings" in his otherworldly place. He goes into the Mermedonian prison unaccompanied by any other people; his only helper is the Holy Spirit, who opens the prison door. Later, he dismisses his disciples and the rescued prisoner, and endures his capture and martyrdom alone. But in contrast to the elegiac landscapes, the otherworldly place where the saint finds himself hosts not an interior crisis, but external conflicts between the saint and the local population. The saint's suffering and eventual victory transforms and sanctifies the otherworldly place. ${ }^{26}$

Andreas twice comes into conflict with the Mermedonians' most monstrous cultural characteristic, their cannibalism: with divine help he deprives them of two potential meals, the foreign Christian prisoners and the sacrificial Mermedonian boy. After his second intervention, the devil leads a posse of warriors against him and orders his imprisonment and torture. As the Mermedonians imprison the saint, winter imprisons the land:

Snaw eorðan band

wintergeworpum. Weder coledon

heardum hægelscurum, swylce hrim ond forst,

hare hildstapan, hæleða eðel

lucon, leoda gesetu. Land wæron freorig

cealdum cylegicelum, clang wæteres prym

ofer eastreamas, is brycgade

blæce brimrade (And 11. 1255-62).

[Snow bound the earth in winter storms. The winds grew cold with hard showers of hail. Likewise, rime and frost, grey warriors, locked up the homeland of men, the habitations of the people. The land was frozen with cold icicles, the glory of the water clung over the streams, the ice bridged the black sea-road.]

But Andreas's martyrdom literally transforms the landscape. After his passion is accomplished, the woods miraculously bloom where his blood has fallen:

Geseh he geblowene bearwas standan

blædum gehrodene, swa he ær his blod aget (And 11. 1448-9).

[He saw blossoming woods stand, adorned with glory, where before he had shed his blood.]

\footnotetext{
25 Howe (2002, p. 109).

26 A similar pattern appears in the Guthlac poems, where the saint ventures into the strange liminal space of his marshy hermitage, all alone among the throngs of hostile demons who claim the swamps as their own territory. For further analysis of this pattern in Guthlac A, see Sharma (2002, pp. 185-200).
} 
Alliteration on ' $b$ ', which encompasses the two verses, falls only on the words that describe either the reviving natural world or the saint's blood ('geblowene bearwas', 'blædum', 'blod').

In the prose analogues, the miracle is a visionary experience, which seems to centre not so much on the landscape itself as on Andreas's flesh and hair, torn away from him under torture. Its miraculous transformation into blooming trees is a literal fulfillment of God's promise to his loyal servants that not even a lock of their hair will perish. In all the prose analogues, God himself describes the vision as "what [Andrew's flesh and hair] has become":

Hec cum intra se orasset beatus andreas, facta est vox domini sermo ebraico dicens ad eum. Amen dico tibi andreas, potest celum et terra transire, quam verbum meum sit vacuum. Nunc autem respice retrorsum, et vide caro tua, et capilli tui quid fiunt. Cum hoc respiceret beatus andreas, apparuerunt caro et capilli sui sicut arbores florentes et fructum afferentes (Casanatensis p. 87, cp. 28).

[When the blessed Andrew had prayed to himself, it happened that the voice of the Lord, speaking to him in Hebrew words, said: "Amen I say to you, Andrew, Heaven and earth can pass away before my word will be empty. Therefore look behind you now and see your flesh and hair, what they have become." When the blessed Andrew looked back, his flesh and hairs appeared as trees blossoming and bearing fruit.]

The Old English homily is almost a word-for-word rendering of this Latin passage. There, too, God literally fulfills his promise, and St. Andrew, looking for his flesh and hair, sees geblowen treow wastm berende ("blossoming trees bearing fruit," LS1.1 11. 251-6).

Conversely, the Old English poem focuses more on Andreas's blood and the blossoming woods than on Andrew's flesh and hair: God shows Andreas the miracle by telling him to look at the blodige stige (bloody path) left behind by his martyrdom (11. 1441-2). To Ananya Jahanara Kabir, the image is "a glimpse of paradise", of the temporary abode of good souls between death and Doomsday. She argues that the natural beauty of the blossoming woods suggests an ideal landscape in terms typical of Old English poetic technique for describing paradise, while its origin in Andreas's blood recalls “Tertullian's declaration that the doors of paradise can be unlocked only by the blood of martyrdom". ${ }^{27}$ However, the prose analogues and the context of the poem itself indicate another interpretation. The prose analogues describe the vision as the literal transformation of a physical object (the saint's flesh and hair) rather than a glimpse of the afterlife. The poem itself also suggests that a momentary vision of paradise might be out of character at this point, for the following two reasons. First, as Kabir herself notes, where the Andreas-poet mentions the afterlife of the blessed, he does not make an explicit distinction between heaven and paradise; as well, he describes the afterlife of the blessed in abstract terms, not in terms of natural beauty. ${ }^{28}$ Second, the miracle happens after

\footnotetext{
27 Kabir (2001, p. 159).

28 Kabir (2001, p. 159).
} 
(and in contrast to) a vivid description of Mermedonia's physical landscape locked in wintry captivity. Given this context, it makes more sense to read the miracle in Andreas as a physical transformation of the natural landscape: rather than momentarily unlocking the gates of paradise, the martyr's blood returns life to the land.

Of course, these two interpretations of the blossoming wood need not be mutually exclusive, for the transformed earthly landscape functions here as a type of the heavenly or paradisal landscape, towards which Andreas himself, functioning as a type of Christ, opens the way for the Mermedonians. ${ }^{29}$ But the Andreas-poet has so consistently used the physical geography of Mermedonia as a sign of its alienation from God, that the miraculous transformation of this very geography is a poetically effective symbol of its inhabitants' spiritual redemption.

The flood which Andreas summons after his martyrdom effects an even profounder transformation. Typologically, the flood recalls both the biblical cataclysm and the sacrament of baptism. ${ }^{30}$ As to the former, the Mermedonians are drowned, just like the monstrous antediluvians, with whom they share the monstrous practice of eating flesh with blood. ${ }^{31}$ As to the latter, the Mermedonians literally enact the Pauline description of baptism:

consepulti ei in baptismo in quo et resurrexistis per fidem operationis Dei qui suscitavit illum a mortuis.

Buried with him in baptism, in whom also you are risen again by the faith of the operation of God, who hath raised him up from the dead. ${ }^{32}$

Terrified by the flood, the Mermedonians convert to Christianity and confess the faith; as soon as they do this, Andreas banishes the flood waters and resurrects all but the most wicked of the dead. These are swallowed up by their own land, as they previously swallowed up other people.

The impression that Andreas's blood has brought spring to the land is strengthened by the flood. This is another correspondence with Beowulf, where the flood-motif is linked with the destruction of monsters. After Beowulf has killed the Grendels, the blade of the monstrous sword he used melts away like ice in the spring, ðonne forstes bend fader onlateð,/onwindeð walrapas ("when the Father releases the bond of frost, unwinds the water-fetters", 11. 1609-10). Later, Hrothgar sees that the hilt of the monstrous sword is seen to be inscribed with fyrngewinnes, suðpan flod ofsloh ... giganta cyn ("the origin of ancient struggle, when the flood ... killed the race of giants", 11. 1689-90). On both of these occasions, a flood (be it that of spring or that of Genesis) is linked to the divinely mandated destruction of monsters. Even more striking is the fact that both the Grendel family and the giganta kyn who are their ancestors are guilty of monstrous eating. Bede,

\footnotetext{
${ }^{29}$ For an extensive summary of arguments in favour of biblical typology in Andreas - the saint as a 'type' of Christ, the flood as a "type" of baptism—see Bjork (1985, pp. 110-111).

30 Ibid.

31 Orchard (2003, p. 141).

32 Colossians 2.12, Douay-Rheims Version.
} 
for instance, points out that the wicked antediluvians cum sanguine carnem comederent, ate flesh together with blood. ${ }^{33}$ In this they resemble the Mermedonians, whose way of life is also wiped out by a flood.

After the Mermedonians and their land emerge from the receding waters, Andreas guides the transformation of their customs and their land: the Mermedonians build and consecrate a church, forsake their old idolatrous altars, and consecrate a bishop (And 11.1633, 1646; 11. 1641-2; 1.1649). As a result, the narrator's descriptive terms for their world are also transformed. Their land is no longer a remote and dangerous place; it becomes, instead, a beorhtan byrig ("a bright city," And 1.1649), a goldburg ("city of gold," 1. 1655), a secga seledream ond sincgestreon ("place of joy and treasure," 1. 1656).

Eventually, Andreas guides the erstwhile monstrous Mermedonians on the path of faith towards their true homeland:

Lærde pa pa leode on geleafan weg,

trymede torhtlice, tireadigra

wenede to wuldre weorod unmæte,

to pam halgan ham heofona rices,

pær fæder ond sunu ond frofre gast

in prinnesse prymme wealdeð

in woruld worulda wuldorgestealda (And 11. 1680-86).

[Then he taught the people on the way of faith, strengthened them gloriously, guided an exceedingly great host of the blessed to blessedness, to the holy home of the kingdom of heaven, where Father and Son and Holy Spirit rule in the glory of the Trinity, for ever and ever, over the dwellings of glory.]

Anita R. Riedinger observes that the concept of "home" in Old English poetry appears "in a series of antitheses - as a part of reward and punishment, as a place of heaven and hell, of birth and death." These antitheses or conceptual reversals, she argues, reveal the "bi-polarity" of Old English poetic structure, an aspect that prevails throughout the corpus. ${ }^{34}$ The hostile otherworldly place that Andreas travels to suggests a fourfold conceptual reversal of this kind. Most obviously, the otherworldly place and its monstrous inhabitants imply their opposite, a "normal world" in the text. Since Andreas is in Achaia when he complains that the land of Mermedonia is foreign to him and very far away, Achaia serves as a reference point, an implied standard for normality. It is the familiar place that Andreas leaves behind in the service of God. But although the "normal world" stands in antithesis to the strange and dangerous lands where the saint travels, it is not a true home in either poem. In Andreas, for good or ill, no earthly home is safe or lasting. The apostles have no fixed homeland, travelling over all the earth, as God commands. Foreigners find no safety in Mermedonia. The wicked Mermedonians and their ancient civilization are not safe either; they are swept away or transformed by the flood and the new religion.

\footnotetext{
$\overline{33}$ Orchard (2003, pp. 140-141).

${ }^{34}$ Riedinger (1995, p. 55).
} 
Inset narratives and allusions amplify the theme of homelessness on earth. On the journey towards Mermedonia, Andreas recounts the miracles of Christ to the ship's captain. In the temple in Jerusalem, Christ calls on the statue of an angelic creature to declare His lineage to the Jews. The stone image immediately springs to life and testifies in His favour:

Ne dorste pa forhylman hælendes bebod

wundor fore weorodum, ac of wealle ahleop,

frod fyrngeweorc, pæt he on foldan stod,

stan fram stane. Stefn æfter cwom,

hlud purh heardne, hleoðor dynede,

wordum wemde (And 11. 735-740).

[It did not dare to neglect the Saviour's command-a wonder before the people-but it leapt from the wall, the wise work of distant days, so that it stood on the ground, stone [parted] from stone. A voice came after, loud through the hard thing; speech resounded, was heard in words.]

The verses vividly depict the strangeness of the moment-the suddenness of the statue's movement, the unnatural separation of stone from stone, the flinty quality of the creature's voice, the surprising emergence of words. The miracle continues: not only does Christ command the statue away from its proper place, He sends it on a mission to call Abraham and his two sons out of their graves, as further witnesses. Just as the lifeless stone is not safe from God's call, neither are the dead in their graves; Abraham, Isaac, and Jacob answer the divine summons in such a hurry that they leave their graves gaping open behind them: [f]orlatan moldern wunigean/ open eorðschrafu ("they forsook dwelling in their sepulchres, open holes in the earth," And 11. 802b).

Neither miracle convinces the High Priest in Jerusalem; he taunts Christ's followers that they are exiles, geographically and ideologically, obeying the teachings of a stranger instead of the customs of the land:

Hwæt, ge syndon earme ofer ealle menn!

Wadað widlastas, weorn geferað

earfoðsiða, ellpeodiges nu

butan leodrihte larum hyrað ... (And 11. 676-82).

[Look, you are miserable above all men! [You] tread long roads, travel on many hard journeys, hear the teaching of a foreigner now, against the custom of the people ...]

The taunt of foreignness does not appear in either of the prose analogues: there, the high priest denies Jesus' divinity, and gets contradicted by the speaking statue (Casanatensis cp. 14, p. 59-61; Praxeis cp. 14, p. 58-60). Ironically, however, the taunt of exile is quite true in the poem: Christ's followers-be they apostles, former anthropophagi, living statues or dead prophets-have no abiding home on earth.

Frequent appearances of the word elpeodig and its cognates underscore this essential human homelessness. In fact, the Andreas-poet uses elpeodig and its cognates twelve times, by far the highest number of this word's occurrences in any 
Old English prose or poetic text. ${ }^{35}$ Used both as an adjective and as a noun, its primary meaning is "foreign, alien." 36 It is part of the Andreas-poet's strategy of distancing Mermedonia from the implied normal world: most of the time, the word refers either to the apostles and other strangers to Mermedonia (six times), or to the Mermedonians themselves, foreign to the apostles (four times). ${ }^{37}$ However, figuratively, elpeodig describes the condition of mortal human beings: in the earthly world, they are foreigners, resident aliens in search of an eternal homeland. ${ }^{38}$ As the poem's insistence on the loss or the instability of homes suggests, the otherworldly land of Mermedonia becomes an expression of the transitory earthly world.

Home is elsewhere. Two other worlds-eternal ones-feature in the poem, in antithesis to one another. One is heaven, the place of wuldorgestealda ("dwellings of glory", And 1. 1684), the holy and eternal home of God, of the patriarchs, of the good angels, and of faithful Christians (And 11. 807-810, 829-30, 1680-6). The other, opposite world is hell, the devil's habitation, the place of eternal captivity and exile. Andreas, taunted by the fiend, describes his condition:

pær ðu syððan a, susle gebunden,

in wræc wunne, wuldres blunne,

syððan ðu forhogedes heofoncyninges word.

pær wæs yfles or, ende næfre

pines wræces weorðeð (And 11. 1379-1383).

[There you have ever since [the Fall] been bound in torment, dwelt in exile, lost glory, since you despised the word of heaven's king. That was the beginning of evil; the end of your exile will never come.]

The land of the Mermedonians is contested ground between these two extremes. At the beginning of the story Mermedonia, with its cannibalistic and idolatrous customs, explicitly belongs to the devil; by the end of the story, its inhabitants, led by Andrew, are on their way to heaven. Mermedonia is poised between these two spiritual opposites. Granted its own abbreviated history of salvation (a Passion, a baptismal flood), the land functions as a miniature representation of the entire human world, encompassed by sin but capable of receiving salvation.

To use a mathematical metaphor, the poem explores the concepts of "home" and "exile" along two perpendicularly intersecting axes. The first axis is that of limited and temporal reality, the human perspective. One end is the "normal world" of the

\footnotetext{
35 The word "elpeodig" and its cognates appear twenty-six times in the Old English poetic corpus and a hundred times in the Old English prose corpus ("elpeodig"). Its frequency in Andreas accounts for almost half of the word's occurrences in the entire Old English poetic corpus: the word and its cognates appear twelve times in Andreas, twenty-six times in Old English verse altogether, and four times in Elene, the poem boasting the next-highest frequency of this word.

36 "elpeodig." Dictionary of Old English in Electronic Form A-F (1996).

37 There are two exceptions: once, "elpeode" is used in the sense of "nations", when Christ tells Andrew that the Crucifixion will become known "on elpeode" (And 970); the other time, it is again used in the sense of foreigner, as the High Priest of Jerusalem disparages Jesus' teachings as those of a foreigner (And 677). The second instance will be discussed below.

38 “elpeodig." Dictionary of Old English in Electronic Form A-F (1996).
} 
text, the expressed or implied human homeland; the opposite end is the hostile otherworld, defined by its monstrous and supernatural elements. The second axis is that of eternal reality. One end is heaven, the one true and permanent homeland; the opposite end is hell, the state of ultimate exile. Initially, the saint travels away from his "normal world" and into a dangerous otherworldly place, choosing what looks like exile for the sake of his faith. But as he comes into conflict with the monstrous inhabitants and prevails over them, the saint measures the otherworldly place against eternity, separating out the demonic elements and sending them into their proper exile, but redeeming the human and natural aspects of this world and drawing it up towards its heavenly home.

Acknowledgements I would like to thank Andy Orchard and Antonette diPaolo Healey for their kind assistance with this essay.

\section{References}

Bjork, R. E. (1985). The Old English verse Saints' lives: A study in direct discourse and the iconography of style. Toronto: University of Toronto Press.

Blatt, F. (Ed.) (1930). Die lateinischen Bearbeitungen der Acta Andrea et Matthia apud anthropophagos. Zeitschrift für die neutestamentliche Wissenschaft und die Kunde der älteren Kirche, Beiheft 12 (1930), 1-197.

Boenig, R. (Ed. and Transl.) (1991). The acts of Andrew in the Country of the Cannibals. New York and London: Garland Publishing, Inc.

Brooks, K. R. (Ed.) (1961). Andreas and the fates of the Apostles. Oxford: Clarendon Press.

Cassidy, F. G., \& Ringler, R. N. (Eds.). (1971) The acts of Matthew and Andrew in the city of the Cannibals. In Bright's Old English grammar and reader (pp. 203-219). New York: Holt, Rinehart and Winston.

Casteen, J. (1978). Andreas: Mermedonian cannibalism and figural narration. Neuphilologische Mitteilungen, 75, 74-78.

Cooke, W. (2003). Two notes on Beowulf (with glances at Vafprúðnismál, Blickling Homily 16, and Andreas, lines 839-846). Medium Avum, 72(2), 297-301.

"Elpeodig." In Dictionary of Old English in electronic form A - F (1996). Antonette diPaolo Healey (Ed.) http://www.doe.utoronto.ca. Available via UofT Libraries: WinFrame Server. Cited 24 July 2007.

"Elpeodig" (simple fragmentary search: "lTeod"). In Dictionary of Old English Corpus on the World Wide Web. Antonette diPaolo Healey (Ed.) http://www.doe.utoronto.ca. Cited 24 July 2007.

Gelling, M. (2002). The landscape of Beowulf. Anglo-Saxon England, 31, 7-11.

Grosz, O. J. H. (1970). The island of exiles: A note on Andreas 15. English Language Notes, 7(4), 240.

Hall, J. R. (1987). Two dark Old English compounds: ælmyrcan (Andreas 432a) and guðmyrce (Exodus 59a). Journal of English Linguistics, 20(1), 38-47.

Howe, N. (2002). The landscape of Anglo-Saxon England: inherited, invented, imagined. In J. Howe \& M. Wolfe (Eds.), Inventing medieval landscapes: Senses of place in western Europe (pp. 91-112). Gainesville: University Press of Florida.

Kabir, A. J. (2001). Paradise, death, and doomsday in Anglo-Saxon literature. Cambridge; New York: Cambridge University Press.

Klaeber, Fr. (Ed.) (1950). Beowulf and the fight at Finnsburg (3rd ed., with 1st and 2d supplements). Boston: D. C. Heath and Company.

Krapp, G. P. (1905). Notes on the Andreas. Medieval Philology, 2, 400.

Krapp, G. P. K., \& Dobbie, E. V. K. (Eds.). (1936). Guthlac A and B. In The Exeter Book. The AngloSaxon Poetic Records, Vol. 3. New York: Columbia University Press.

Morris, R. (Ed.) (1874-80, repr. 1967). The blickling homilies. Early English Text Series o.s. 58, 63, 73. London: Oxford University Press.

Orchard, A. (2003). A critical companion to Beowulf. Woodbridge, UK; Rochester, NY: D.S. Brewer. 
Powell, A. M. (2002). Verbal parallels in Andreas and its relationship to Beowulf and Cynewulf. Dissertation, University of Cambridge.

Riedinger, A. R. (1995). 'Home' in Old English poetry. Neuphilologische Mitteilungen, 96, 51-59.

Sharma, M. (2002). A reconsideration of Guthlac A: The extremes of saintliness. Journal of English and Germanic Philology, 101, 185-200.

Skeat, W. V. (Ed.) (1881-1900, repr. 1966). Alfric's Lives of Saints. Early English Text Series o.s. 76, 82, 94, 114. London: Oxford University Press.

Swisher, M. (2002). Beyond the hoar stone. Neophilologus, 86(1), 133-136.

The Holy Bible: Douay-Rheims Version (New Testament first published at Rheims, 1582; repr. 1914). Translated from the Latin Vulgate. New York: P. J. Kenedy \& Sons, Printers to the Holy See. 